The Canadian Journal of Higher Education, Vol. XXIII-3, 1993

La revue canadienne d'enseignement supérieur, Vol. XXIII-3, 1993

\title{
Time Use and Educational Attainment: A Study of Undergraduate Students
}

\section{EMILY J. ETCHEVERRY, ${ }^{*}$ RODNEY A. CLIFTON, ${ }^{*}$ \& LANCE W. ROBERTS*}

\section{Abstract}

This research examines the effects of students' time use in academically related activities and paid employment on their educational attainment. A theoretical model containing fourteen background, social psychological, time use, and educational attainment variables was formulated. The data were obtained from questionnaires administered to 308 undergraduate students in the Faculty of Education at a Western Canadian University. A stratified random cluster sampling procedure was used to select classes of students. Structural equation modelling is used to test the relationships among the variables. Results indicate that when other variables are taken into account, the time students spend in academically related activities and paid employment has little effect on their educational achievement and their educational expectations.

\section{Résumé}

Cette recherche examine les effets de la répartition du temps d'étude et du temps alloué à un emploi sur le succès académique des étudiants. Un modèle théorique comportant quatorze variables de type général, socio-psychologique, d'utilisation du temps, et portant sur les résultats de l'expérience éducative, a été développé. Les données ont été obtenues d'une enquête effectuée auprès de 308 étudiants non diplômés de la faculté d'éducation d'une université canadienne. Une méthode

* University of Manitoba 
d'échantillonnage stratifié par groupe a été utilisée pour sélectionner les groupescibles d'étudiants. Une modélisation par équation structurale a été effectuée pour analyser les résultats. Ils indiquent, qu'une fois l'effet des autres variables pris en compte, le temps dédié aux activités académiques et à un emploi rémunéré a peu d'impact sur le succès académique des étudiants et sur leurs attentes en matière de formation.

Numerous studies of college students have taken into account the effects of socioeconomic status, age, gender, and social psychological factors on their educational attainment. However, the way in which college students use their time working, studying, and attending classes has been generally overlooked (see Anderson, 1988; Drew \& Astin, 1977; Reitzes \& Mutran, 1980). This failure to include time use in models of educational attainment of college students is curious for two reasons. First, university students have considerable discretion about the way they use their time. This discretion is evident in the number of courses students select, as well as in the amount of time they spend in classes, studying, and working. Given that students need to balance their time commitments to various roles, it is worth examining how the way they allocate their time affects their academic success.

The second reason for examining the effects of time use is that previous literature on time and learning suggests a positive relationship between time spent in learning activities, such as studying and attending class, and grades. If time spent in learning activities has a positive effect on achievement, it may also have a similar effect on educational expectations and status attainment. Conversely, the time students spend in activities such as employment may have a negative effect on educational attainment. Since student employment is increasingly common in both Canada and the United States (D'Amico, 1984; Grogan, 1989), and little is understood about the effects of time spent in employment on the educational attainment of university students, this relationship deserves systematic investigation.

\section{The Theoretical Model}

This study contributes to the literature by linking social background, social psychological characteristics, time use and educational attainment. Socioeconomic status, gender and age are social background factors which have been shown to be linked to educational attainment. In Western societies, parental socioeconomic status is considered as a precursor of students' educational outcomes. Generally, students with lower socioeconomic status have lower 
educational achievement than students with higher socioeconomic status (Boocock, 1980; Brookover, \& Erickson, 1975; Miller, 1970; Porter, Porter, \& Blishen, 1982). For college students, Reitzes and Mutran (1980) show weak positive relationships between socioeconomic status and both students' grades and educational expectations. To a large extent, these relationships are mediated by social psychological variables.

Generally, the effects of gender and age on educational attainment have been equivocal. According to Porter et al., (1982), females have lower educational expectations and lower levels of actual attainment at the college level than males; but some research on college students suggests that gender does not influence educational attainment (Metzner \& Bean, 1987; Reitzes \& Mutran, 1980). Also, it has been reported that younger college students generally achieve higher grades than older college students (Miller, 1970), but Kasworm (1980) and Metzner and Bean (1987) found that older students have higher achievement than younger students.

The social psychological variables self-concept of ability and motivation are considered to be significant predictors of educational attainment (Brookover \& Erickson, 1975; Clifton \& Roberts, 1988; Gordon, 1972; Heckhausen, 1967; Marjoribanks, 1976; Miller, 1970; Porter, Porter, \& Blishen, 1982; Reitzes \& Mutran, 1980). These studies suggest that self-concept of ability and motivation intervene between background characteristics and grades and educational expectations. Likewise, we argue that the ways students use their time also intervenes between background characteristics and educational attainment.

Literature on time and learning suggests that the ways in which students spend their time may account for differences in their educational achievement and expectations. There are two groups of studies relating time and learning (Daniels \& Haller, 1981). The first group examines exposure time in school. These studies indicate that, in general, the more time that students spend in school the higher is their academic achievement (Goodlad, 1984; Heyns, 1978; Wiley \& Harnischfeger, 1974). Although these studies concern primary and secondary school students, the relationship between time use and achievement may be also true for college students. Metzner and Bean (1987) found that students who were more often absent from class had lower academic achievement than students who were less often absent from class. In addition, they reported that students who enrolled in fewer credit hours were more likely to drop out of college, and therefore not attain their educational goals, than students enrolled in more credit hours. These findings support the idea of a link between time spent in learning and educational attainment, and suggest that 
there may be a cumulative advantage for students who take more courses and who attend classes more regularly.

The second group of studies examines time engaged in learning activities. Generally, these studies indicate positive relationships between time spent learning and achievement (Bloom, 1974; Heyns, 1978; Karweit, 1984; Karweit \& Slavin, 1982; Keith, 1982; Keith, Reimers, Fehrmann, Pottbaum, \& Aubey, 1986; Metzner \& Bean, 1987; Paschal, Weinstein, \& Walberg, 1984; Strother, 1984; Wiley \& Harnischfeger, 1974). Studies by Miller (1970), Polachek, Kniesner, and Harwood (1978) and Wagstaff and Mahmoudi (1976) provide evidence of positive relationships between class hours, study time, time spent on homework, and the educational achievement of college students.

Understanding how time allocation affects the educational attainment of university students is complicated because these students typically assume multiple statuses, such as employee, volunteer, friend, and family member. Involvement in each of these statuses often requires a considerable time commitment for students. Role theory identifies two opposing views of the possible effects of such involvement in multiple statuses. Role conflict theory suggests that involvement in multiple statuses creates conflicts for limited resources, such as time, which are needed to carry out role behaviour (Goode, 1960). Role expansion theory, on the other hand, suggests that involvement in multiple statuses stimulates energy and enhances goal achievement (Marks 1977; Moen, Dempster-McClain, \& Williams, 1989; Thoits, 1983).

Mirroring these opposing views of role theory, the previous literature on student employment presents little consistent information about the effects of time spent in employment on educational achievement and expectations (Finch \& Mortimer, 1985). Some studies suggest positive effects (Radwanski, 1987; D'Amico, 1984); others suggest negative effects (Wagstaff \& Mahmoudi, 1976); and still others indicate no effect (Metzner \& Bean, 1987; Van-de-Water \& Augenblick, 1987). Where positive effects of employment are identified, they are generally associated with students working fewer than 15 to 20 hours a week, while the negative effects are generally associated with students working more than 15 to 20 hours (D'Amico, 1984; Hammes \& Haller, 1983; Radwanski, 1987). Nevertheless, two studies of college students found no significant relationship between the number of hours they spent working and their achievement (Metzner \& Bean, 1987; Van-de-Water \& Augenblick, 1987). These non-significant effects of time may result from the discretion students have over the number of credit hours they take in college. Specifically, students may limit the number of credit hours in which they enroll in relation to the 
Figure 1

The Theoretical Model

Background

Social Psychological

Time Use

Educational Attainment

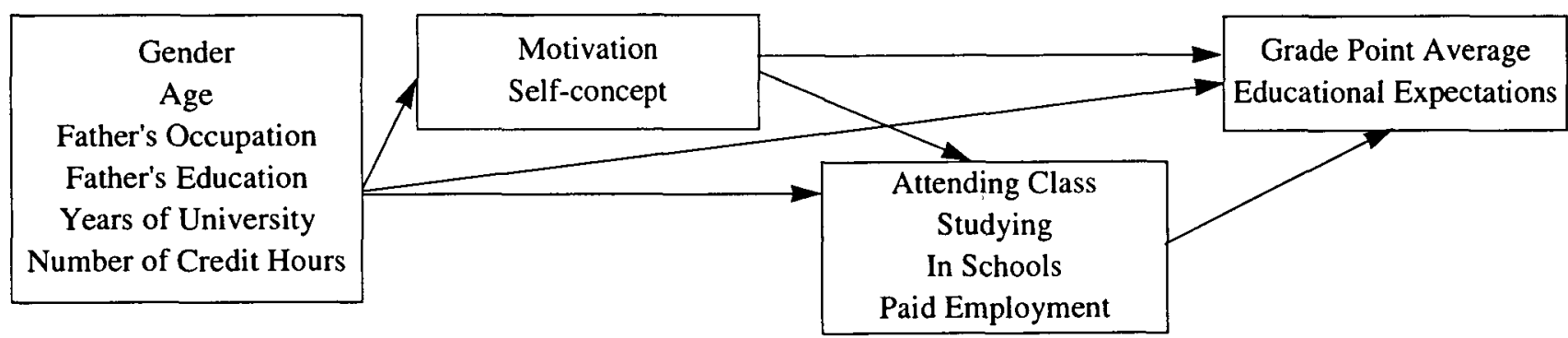


number of hours they work, in order to ensure that they have adequate time to attain satisfactory grades.

In summary, the unique component of the theoretical model used in this study is the addition of time use and its direct and indirect effects on achievement and educational expectations. The discretion that students have in their use of time, the growing trend among students to hold jobs while studying full-time, and the existing empirical literature all support the proposal to examine the effects of time use on educational attainment.

The theoretical model used in this study is presented in Figure 1. In this model, students' educational achievement and expectations are determined by time use, social psychological, and background variables. The inclusion of time use variables between the background and social psychological variables, on the one hand, and the educational attainment variables, on the other, permits us to estimate their mediating effects. Thus, the main focus of this study is on the direct effects of the time use variables on educational achievement and expectations, and on the indirect effects of the background and social psychological variables as they are mediated by the time use variables. It is hypothesized that the time students spend in academic activities has a positive effect on grades and educational expectations, and that the time students spend in employment has a threshold effect. Specifically, it is hypothesized that when time spent in employment is high, the effects on educational achievement and expectations will be negative, and when time spent in employment is low, the effects on educational achievement and expectations will be either neutral or positive.

\section{Methodology}

\section{The Sample}

In 1987 the Faculty of Education at a Western Canadian University conducted a study of its students and programs. A stratified random cluster sampling procedure was used to select undergraduate students to receive questionnaires. The procedure involved randomly selecting classes of students from all courses that students were required to take within each year of the undergraduate Bachelor of Education and Bachelor of Education/After Degree programs. Nineteen classes, representing approximately 27 percent of the population of students, were selected. In total 397 students were enrolled in these classes, and $308 \mathrm{stu}-$ dents completed questionnaires. This represents a return rate of approximately 76 percent. 
Thirty-five percent of respondents were male and 65 percent were female; 46 percent of respondents were between the ages of 21 and 25; and approximately 50 percent of the students reported being employed. The gender distribution of the sample was similar to that of the student population in the Faculty of Education during the study, and the percentage of students who were employed is similar to the percentage of employed undergraduate students at the university (Walker, 1989).

\section{The Variables}

In total, fourteen variables were used in this study. Six background variables were measured. Gender was treated as a dummy variable with males coded as 1 and females coded as 2 . Responses to the question "How old are you?" provided data for age. Ages were coded into single years from 18 to 28 , and recoded into four groups for students who were 29 or older in order to normalize the distribution. The students indicated their fathers' occupations by selecting from a standard hierarchical list of 15 categories ranging from farm labourers, coded 1 , to self-employed professionals, coded 15. Father's education was measured on a nine-point continuum ranging from elementary school to completed graduate degree. Years of university education was measured by the question "How many years of university education do you have? If you have been a part-time student, then estimate the number of equivalent full-time years." Students reported years of university ranging from 1 to 6 years. Fifty-two percent of respondents reported having fewer than 4 years of university experience. Credit hours were measured by students' report of the number of credit hours of university work they were taking during the academic year. Ninety-two percent of respondents were taking 18 or more credit hours of study, and 41 percent were taking a full course load of 30 credit hours.

Two social psychological variables were measured. Motivation was measured on a five-point scale, with 1 indicating unmotivated and 5 indicating very motivated in response to the question "Please check how motivated you are to do well in your courses this year." To measure self-concept of ability, students were asked "How good are you at your university work compared to other students in your year level?" The five response choices ranged from a lot below average to a lot above average. Fifty-eight percent of respondents considered themselves highly motivated and 82 percent of respondents considered their work to be about, or a little above, average.

Four variables measured the ways in which students use their time. Attending class, studying, student teaching/volunteer time in schools, and paid employment were each measured by the number of hours that students indicated 
that they spent in a "typical week" in each of these activities. The request for estimates of a "typical week" avoided estimates for a single day or a single week which would not likely be characteristic of students' general use of time, even though more reliable data may have been obtained by asking students to recall their use of time for a shorter, more recent period of time (see Baker, D'Amico, \& Nestel, 1983). For each of the time use variables, time was coded into 5 hour intervals. The majority of students spent from 11 to 15 hours per week in class and 6 to 15 hours per week studying. Sixty-five percent of the students spent time teaching or volunteering in schools, and 49 percent of them reported spending time in paid employment.

Finally, student educational attainment was measured by two variables. Academic achievement was measured by self-reported responses of grade point average (GPA), ranging from $\underline{0}$ to $\underline{4.0}$. Thirty-nine percent of respondents reported achieving GPAs of 3.0 to $3.4 ; 28$ percent reported achieving GPAs greater than 3.4; and 33 percent reported achieving GPAs less than 3.0. Educational expectations were based on the question, "What is the highest level of education you expect to complete?" and responses ranged on a six-point scale from less than a bachelor's degree to a doctorate degree. Slightly over 50 percent of the students expected to complete a bachelor's degree, and the other 50 percent expected to complete a second bachelor's degree or a graduate degree.

\section{The Procedure}

In order to test the theoretical model, the data were analyzed using structural equation modelling techniques (Pedhazur, 1982). Pearson product moment correlations between all variables in the model, and regression coefficients, were computed to estimate the magnitude of relationships between the independent and dependent variables when other variables are controlled. In addition, regression coefficients to estimate the effects of the interaction between numbers of credit hours and paid employment on the dependent variables were included in the analyses. This was done because previous literature suggested that the effect of paid employment on academic achievement may differ depending on the numbers of hours students are employed. More specifically, it has been argued that 15 to 20 hours of employment per week has been identified as a threshold (D'Amico, 1984; Hammes \& Haller, 1983). Hours of employment greater than this threshold are often considered to detract from educational achievement and expectations. This interaction effect may be examined by using a multiplicative term between credit hours and paid employment (Jaccard, Turrisi, \& Wan, 1990, p. 21). 


\section{Results}

\section{Zero Order Relationships}

The correlation matrix, means, and standard deviations are presented in Table 1. Prior to taking into account other variables, several zero-order correlations related to the time use variables, studying, and paid employment are of interest. The time students spend studying is positively related to educational achievement and expectations. In other words, as one might expect, achievement and educational expectations are higher for students who study more hours per week than for those who study fewer hours. Not surprisingly, the number of credit hours in which students are enrolled and the number of hours they report attending classes each week are both positively related to hours spent studying. Motivation and self-concept of ability are also positively related to studying. Students with higher levels of motivation and more positive self-concepts spend more hours studying than students with lower levels of motivation and less positive selfconcepts.

The time students spend in paid employment is negatively correlated with educational achievement, indicating that those students who work greater numbers of hours per week have lower achievement than students who work less. Negative correlations between age and paid employment and between credit hours and paid employment indicate that older students and students enrolled in greater numbers of credit hours are employed for fewer hours per week than younger students and students enrolled in a smaller number of credit hours. Two time use variables, attending class and studying, are also negatively correlated with paid employment. This indicates that students who are employed for more hours per week attend class and study less than students who are employed for fewer hours per week.

\section{Multivariate Relationships}

In Table 2 the standardized and unstandardized effect parameters are reported for the time use variables. The reduced form parameters are reported in Step 1 and the fully recursive parameters are reported in Step 2. Net of the other independent and intervening variables, number of credit hours has a large positive effect on attending class (.486), a somewhat smaller positive effect on studying (.288), and a negative effect on paid employment (-.288). In other words, students who are enrolled in more credit hours are more likely to attend classes and study, and are less likely to be employed for extended periods of time, than students who are enrolled in fewer credit hours. In addition, older students are less likely to spend 


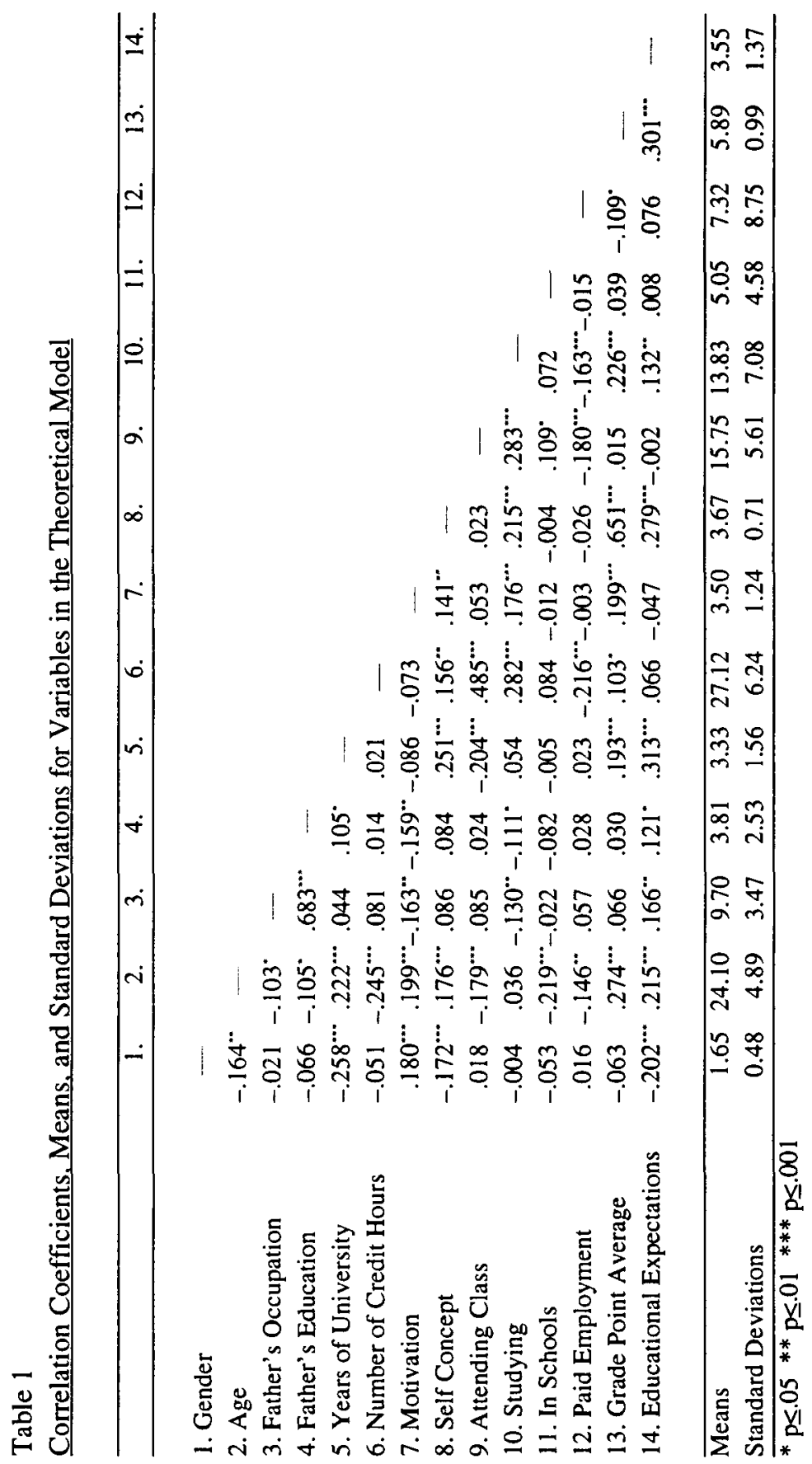


Table 2

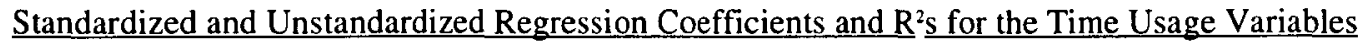

\begin{tabular}{|c|c|c|c|c|c|c|c|c|}
\hline \multirow{2}{*}{$\begin{array}{l}\text { Independent } \\
\text { Variables } \\
\end{array}$} & \multicolumn{2}{|c|}{ Attending Class } & \multicolumn{2}{|c|}{ Studying } & \multicolumn{2}{|c|}{ In Schools } & \multicolumn{2}{|c|}{ Paid Employment } \\
\hline & Step 1 & Step 2 & Step 1 & Step 2 & Step 1 & Step 2 & Step 1 & Step 2 \\
\hline 1. Gender & $\begin{array}{c}-.014 \\
(-.166)\end{array}$ & $\begin{array}{c}-.035 \\
(-.406)\end{array}$ & $\begin{array}{c}.035 \\
(.523)\end{array}$ & $\begin{array}{c}.020 \\
(.298)\end{array}$ & $\begin{array}{c}-.092 \\
(-.882)\end{array}$ & $\begin{array}{l}-.100 \\
(-.955)\end{array}$ & $\begin{array}{c}-.018 \\
(-.333)\end{array}$ & $\begin{array}{c}-.023 \\
(-.415)\end{array}$ \\
\hline 2. Age & $\begin{array}{c}-.009 \\
(-.011)\end{array}$ & $\begin{array}{c}-.028 \\
(-.032)\end{array}$ & $\begin{array}{l}.095 \\
(.137)\end{array}$ & $\begin{array}{c}.034 \\
(.049)\end{array}$ & $\begin{array}{l}-.251^{\cdots} \\
(-.235)\end{array}$ & $\begin{array}{l}-.264^{* * *} \\
(-.248)\end{array}$ & $\begin{array}{l}-.233^{\cdots *} \\
(-.417)\end{array}$ & $\begin{array}{l}-.247^{\cdots} \\
(-.442)\end{array}$ \\
\hline $\begin{array}{l}\text { 3. Father's } \\
\text { Occupation }\end{array}$ & $\begin{array}{c}.051 \\
(.083)\end{array}$ & $\begin{array}{c}.062 \\
(.101)\end{array}$ & $\begin{array}{l}-.138 \\
(-.282)\end{array}$ & $\begin{array}{c}-.132 \\
(-.268)\end{array}$ & $\begin{array}{l}.055 \\
(.072)\end{array}$ & $\begin{array}{c}.059 \\
(.077)\end{array}$ & $\begin{array}{l}.101 \\
(.254)\end{array}$ & $\begin{array}{l}.103 \\
(.259)\end{array}$ \\
\hline $\begin{array}{l}\text { 4. Father's } \\
\text { Education }\end{array}$ & $\begin{array}{c}.004 \\
(.008)\end{array}$ & $\begin{array}{c}.009 \\
(.019)\end{array}$ & $\begin{array}{c}-.013 \\
(-.036)\end{array}$ & $\begin{array}{c}-.013 \\
(-.035)\end{array}$ & $\begin{array}{c}-.157^{*} \\
(-.283)\end{array}$ & $\begin{array}{c}-.155^{*} \\
(-.281)\end{array}$ & $\begin{array}{c}-.071 \\
(-.244)\end{array}$ & $\begin{array}{c}-.070 \\
(-.243)\end{array}$ \\
\hline $\begin{array}{l}\text { 5. Years of } \\
\text { University }\end{array}$ & $\begin{array}{l}-.219^{\cdots} \\
(-.785)\end{array}$ & $\begin{array}{l}-.207^{\cdots} \\
(-.743)\end{array}$ & $\begin{array}{l}.042 \\
(.192)\end{array}$ & $\begin{array}{c}.027 \\
(.120)\end{array}$ & $\begin{array}{l}.041 \\
(.119)\end{array}$ & $\begin{array}{l}.042 \\
(.122)\end{array}$ & $\begin{array}{l}.079 \\
(.441)\end{array}$ & $\begin{array}{c}.076 \\
(.426)\end{array}$ \\
\hline $\begin{array}{l}\text { 6. Number of } \\
\text { Credit Hours }\end{array}$ & $\begin{array}{l}.483 \cdots \\
(.434)\end{array}$ & $\begin{array}{l}.486 \cdots \\
(.437)\end{array}$ & $\begin{array}{l}.318^{\cdots *} \\
(.360)\end{array}$ & $\begin{array}{l}.288^{\cdots} \\
(.327)\end{array}$ & $\begin{array}{c}.014 \\
(.011)\end{array}$ & $\begin{array}{c}.012 \\
(.008)\end{array}$ & $\begin{array}{c}-.282^{\cdots} \\
(-.396)\end{array}$ & $\begin{array}{l}-.288^{\cdots} \\
(-.405)\end{array}$ \\
\hline 7. Motivation & & $\begin{array}{c}.096 \\
(.436)\end{array}$ & & $\begin{array}{l}.144^{\circ} \\
(.822)\end{array}$ & & $\begin{array}{c}.046 \\
(.169)\end{array}$ & & $\begin{array}{c}.036 \\
(.258)\end{array}$ \\
\hline 8. Self Concept & & $\begin{array}{c}-.021 \\
(-.170)\end{array}$ & & $\begin{array}{c}.152^{* *} \\
(1.529)\end{array}$ & & $\begin{array}{l}.015 \\
(.095)\end{array}$ & & $\begin{array}{c}.031 \\
(.388)\end{array}$ \\
\hline
\end{tabular}

\begin{tabular}{llllrrrrr}
\hline $\mathrm{R}^{2}$ & .285 & .292 & .115 & .160 & .073 & .075 & .100 & .102 \\
\hline a Unstandardized coefficients in parenthesis & & ${ }^{*} \mathrm{p} \leq .05$ & ${ }^{* *} \mathrm{p} \leq .01$ & ${ }^{* * *} \mathrm{p} \leq .001$ & & &
\end{tabular}


Table 3

Standardized and Unstandardized Regression Coefficients and $\mathbf{R}^{2}$ sor the Educational Attainment Variables

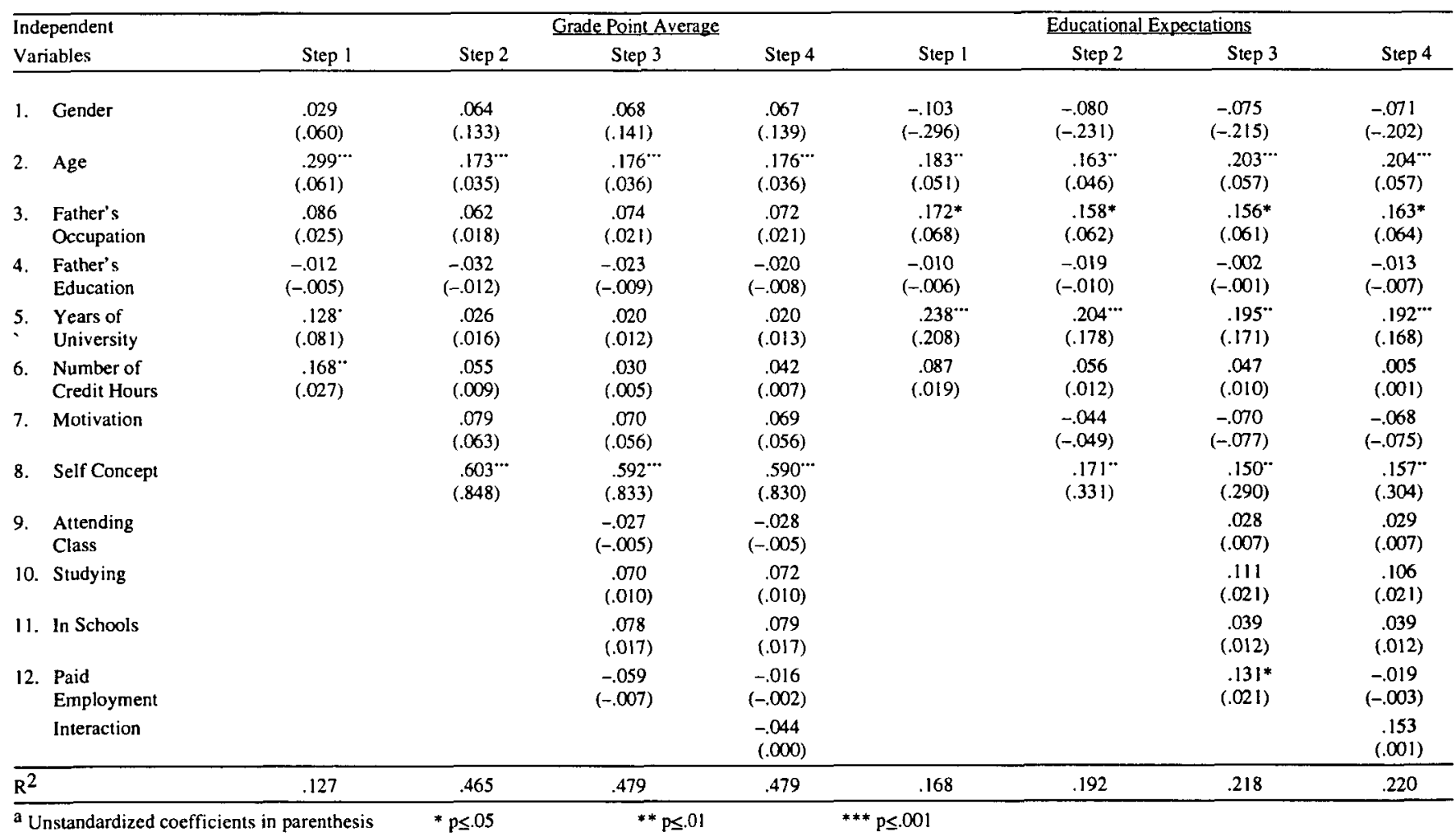


time volunteering in schools (-.264) and are less likely to be engaged in paid employment $(-.247)$ than younger students. Finally, both motivation and selfconcept of ability are positively related to the amount of time students spend studying (.144 and .152 respectively).

It is interesting to note that very little of the effect of either the social background variables or the university background variables are mediated by the social psychological variables. In other words, adding motivation and self-concept of ability to the analyses (Step 2) does not have much effect on the relationships between the independent variables and the time use variables. Moreover, the social psychological variables add little to the amount of variance explained in the time use variables. Specifically, when the social psychological variables are added in the fully recursive model, the amount of variance explained in attending class, volunteering in schools, and paid employment is increased by less than one percent while the amount of variance explained in studying is increased by approximately 4.5 percent.

In Table 3 both reduced form (Steps 1 and 2) and fully recursive parameters (Step 3) for the variables which affect the educational attainment variables, grade point average and educational expectations, are presented. Here we can see that the effects of the time use variables are relatively small. Surprisingly, the amount of time students spend attending class has a very small effect on grade point average (-.027) and expectations (.028). Studying only has a small positive effect on grade point average (.070) and a slightly larger positive effect on educational expectations (.111). Similarly, the amount of time students spend volunteering/student teaching in schools has a small positive effect on grade point average (.078) and a smaller positive effect on educational expectations (.039). Paid employment has only a small negative effect on grade point average (-.059) and, surprisingly, a significant positive effect (.131) on educational expectations. In addition, when the time use variables are added to the model, the amount of variance in grade point average is increased by 1.4 percent (from .465 to .479 ), and the amount of variance in educational expectations is increased by 2.6 percent (from .192 to .218 ).

Nevertheless, some of the other variables in the model have important effects on the educational attainment variables. Taking into account all other variables, self-concept of ability has a large positive effect on grade point average (.592) and a moderately positive effect (.150) on educational expectations. Similarly, age has a strong effect on both grade point average (.176) and educational expectations (.203). Year of university and father's occupation also have effects on educational expectations (.195 and .156 respectively). 
In Step 4, the interaction between credit hours and paid employment is introduced into the analyses to test for a non-linear relationship between employment and educational attainment. The effect of this term is -.044 on grade point average and .153 on educational expectations. At the same time, the interaction term reduces the effect of paid employment on both grade point average (from - .059 to-.016) and educational expectations (from .131 to -.019). In other words, when this interaction term is entered into the analyses, it reduces the effect of paid employment from a significant positive effect to zero on educational expectations. Nevertheless, the amount of additional variance explained by this term is zero percent for grade point average and 0.2 percent for educational expectations. These findings fail to support the idea of a non-linear relationship between paid employment and educational attainment.

In summary, these results suggest that the way students spend their time-whether it is in attending classes, studying, volunteering/student teaching in schools, or in paid employment--has little effect on their educational attainment, and that the interaction between the number of credit hours and paid employment has little effect on educational attainment.

\section{Discussion}

Emerging from the zero order relationships in this study are two significant findings relating time use and educational attainment. First, there are positive relationships between studying and GPA and between studying and educational expectations. Second, there is a negative relationship between hours spent in paid employment and grade point average. However, the model used in this study links social background, social psychological characteristics, time use and educational attainment and allows multivariate analyses of the time use variables. When the results of multivariate analysis are taken into account, the relationships between studying and educational attainment and between employment and educational attainment are shown to be explained to a considerable degree by other variables.

Credit hours, motivation, and self-concept of ability are the variables which account for the relationship between studying and grade point average. Students taking more courses and who have more positive social psychological dispositions study more and have higher achievement than students who take fewer courses and who have less positive social psychological dispositions. This suggests that students do better when they are motivated, when they think they can do well, and when they are involved in a significant academic workload. One explanation for the influence of heavier workloads may be that students who 
take more credit hours of course work are more challenged and more committed to their programs than students who enrol in fewer credit hours. Challenged and committed students may have enhanced self-concepts of ability and motivation which result in increased time spent studying, and ultimately higher grades and educational expectations.

The negative correlation between paid employment and educational achievement suggests that students who are employed for more hours have lower achievement than students who are employed for fewer hours. However, in the multivariate analysis, the relationship between paid employment and achievement, although still negative, is not significant. On further examination it is evident that age and credit hours account for most of this relationship. Older students and students taking more credit hours are more likely to work less than younger students and students taking fewer credit hours of academic work.

The finding that paid employment has no effect on educational attainment, when other factors are taken into account, suggests that university students effectively balance time demands so that their academic goals are not compromised. Furthermore, since this study also indicates that the time students spend attending class has little effect on educational attainment, there is further support for the idea that students use their time effectively in achieving their academic goals. In fact, older and more experienced students may have learned that generally they can succeed academically without attending all their classes. Moreover, these students may learn more effectively when they study by themselves rather than when they attend classes.

Overall, the results suggest that these undergraduate students adjust the number of credit hours they are taking and the amount of time they are working at a job so that their grades and their educational expectations do not suffer. In this way, the results of this study do not support the role conflict theory, nor do they support the role expansion theory. Rather, it seems the results suggest that the amount of time students are involved in other roles has virtually no impact upon their educational attainment. 


\section{References}

Anderson, K. L. (1988). The impact of colleges and the involvement of male and female students. Sociology of Education, 61, 160-177.

Baker, P., D'Amico, R., \& Nestel, G. (1983). Measuring time use: A comparison of alternate research strategies. Unpublished manuscript. Center for Human Resource Research, Ohio State University

Bloom, B. S. (1974). Time and leaming. American Psychologist, 29, 682-688.

Boocock, S. S. (1980). Sociology of Education (2nd ed.). Boston: Houghton Mifflin Co.

Brookover, W. B., \& Erickson, E. L. (1975). Sociology of Education. Homewood, Il.: The Dorsey Press.

Clifton, R. A., \& Roberts, L. W. (1988). Social psychological dispositions and academic achievement of Inuit and non-Inuit students. The Alberta Journal of Educational Research, 24, 332-343.

D'Amico, R. (1984). Does employment during high school impair academic progress? Sociology of Education, 57, 152-164.

Daniels, A. F., \& Haller, E. J. (1981). Exposure to instruction, surplus time, and student achievement: A local replication of the Harnischfeger and Wiley research. Educational Administration Quarterly, 17, 48-68.

Drew, D. E., \& Astin, A. W. (1977). Undergraduate aspirations: A test of several theories. American Journal of Sociology, 77, 1151-1164.

Finch, M. D., \& Mortimer, J. T. (1985). Adoleseent hours and the process of achievement. Research in Sociology, 5, 171-196.

Goode, W. J. (1960). A theory of role strain. American Sociological Review, 25, 483-496.

Goodlad, J. I. (1984). A place called school: Prospects for the future. Ncw York: McGrawHill.

Gordon, C. (1972). Looking ahead: Self conception, race and family as determinants of adolescent orientation to achievement. Washington DC: American Sociological Association.

Grogan, L. (1989, April 24). Young money: Spending power of tecns has rocketed. The Financial Post, p. 15.

Hammes, J. F., \& Haller, E. J. (1983). Making ends meet: Some of the consequences of part-time work for college students. Journal of College Student Personnel, 24, 529535.

Heckhausen, H. (1967). The anatomy of achievement motivation. New York: Academic Press.

Heyns, B. (1978). Summer learning and the effects of schooling. New York: Academic Press.

Jaccard, J., Turrisi, R., \& Wan, C. K. (1990). Interaction effects in multiple regression. Sage University paper scrics on Quantitative Applications in the Social Sciences, 07-072. Newbury Park, CA: Sage.

Karweit, N. L. (1984). Time on task: A research review. In Time and learning. Bloomington: Phi Delta Kappa.

Karweit, N. L., \& Slavin, R. E. (1982). Time on task: Issues of timing, sampling and definition. Journal of Educational Psychology, 74, 844-851.

Kasworm, C. E. (1980). The older student as an undergraduatc. Adult Education, 31, 30-47. 
Keith, T. Z. (1982). Time spent on homework and high school grades: A large sample path analysis. Journal of Educational Psychology, 74, 248-253.

Keith, T. Z., Reimers, T. M., Fehrmann, P. G., Pottbaum, S. M., \& Aubey, L. W. (1986). Parental involvement, homework, and TV time: Direct and indirect effects on high school achievement. Journal of Educational Psychology, 78, 373-380.

Marjoribanks, K. (1976). School attitudes, cognitive ability, and academic achicvement. Journal of Educational Psychology, 68, 653-660.

Marks, S. (1977). Multiple roles and role strain: Some notes on human energy, time, and commitment. American Sociological Review, 42, 921-936.

Metzner, B. S., \& Bean, J. P. (1987). The estimation of a conceptual model of nontraditional undergraduate student attrition. Research in Higher Education, 27, 15-38.

Miller, G. W. (1970). Success, failure and wastage in higher education. London: Harrap.

Moen, P., Dempster-McClain, D., \& Williams, R. M., Jr. (1989). Social integration and longevity: An event history analysis of women's roles and resilience. American Sociological Review, 54, 635-647.

Paschal, R. A., Weinstein, T., \& Walberg, H. T. (1984). The effects of homework on learning: A quantitative synthesis. Journal of Educational Research, 78, 97-104.

Pedhazur, E. J. (1982). Multiple regression in behavioral research. New York: Holt, Rinchart \& Winston.

Polachek, S. W., Kniesner, T. J., \& Harwood, H. J. (1978). Educational production functions. Journal of Educational Statistics, 3, 209-231.

Porter, J., Porter, M., \& Blishen, B. R. (1982). Stations and callings: Making it through the school system. Toronto: Methuen.

Radwanski, G. (1987). Ontario study of the relevance of education and the issue of dropouts. (Report No. 72711935). Toronto: Ministry of Education.

Reitzes, D. C., \& Mutran, E. (1980). Significant others and self conceptions: Factors influencing educational expectations and academic performance. Sociology of Education, 53, 21-32.

Strother, D. B. (1984). Practical applications of research: Another look at time-on-task. In Time and learning. Bloomington: Phi Delta Kappa.

Thoits, P. A. (1983). Multiple identities and psychological well-being: A reformulation and test of the social isolation hypothesis. American Sociological Review, 48, 174-187.

Van-de-Water, G., \& Augenblick, J. (1987). Working while studying: Does it matter? An examination of the Washington State Work Study Program. Olympia, WA: Higher Education Coordinating Board, 908 East 5th, EW-11, Olympia, WA 98504. (ERIC Document Reproduction Service No. ED 290 356)

Wagstaff, R., \& Mahmoudi, H. (1976). Relation of study behaviours and employment to academic performance. Psychological Reports, 38, 380-382.

Walker, J.L. (1989). University of Manitoba student affairs survey:1989 final report. Winnipeg: Author.

Wilcy, D. E., \& Harnischfeger, A. (1974). Explosion of a myth: Quantity of schooling and exposure to instruction, major educational vehicles. Educational Researcher, 3, 2-12. 